\title{
CRAYFISH OF THE UPPER SOCA AND UPPER SAVA RIVERS, SLOVENIA.
}

\author{
Y. MACHINO
}

13 rue Montorge, 38000 Grenoble, France.

\begin{abstract}
Crayfish biogeography of northwestern Slovenia was studied in the Upper Soca River (Mediterranean drainage) and the Sava Dolinka River (Danubian drainage). The Mediterranean drainage has white-clawed crayfish (Austropotamobius pallipes) and the Danubian drainage has stone crayfish ( $A$. torrentium). Morphological data of these $A$. pallipes suggest that the Slovenian white-clawed crayfish belong to the Austropotamobius pallipes italicus complex. The biogeographic and morphological data support the present general knowledge that in Slovenia the white-clawed crayfish belongs to a Po-Adriatic fauna and the stone crayfish to a Danubian fauna. A third species, the noble crayfish (Astacus astacus), was found in Danubian waters, but its biogeographic meaning may not be significant because the species is present in, and has been introduced into, waters of both the Mediterranean and Danubian drainages. The noble crayfish from a Slovenian lake, Blejsko jezero, has certain morphological characteristics that require additional investigations before its taxonomic position can be clarified. The stone crayfish of the Sava Dolinka now survives in only a few sites, relics of a former wider distribution destroyed by human activities. On the other hand, the white-clawed crayfish of the Soca is still distributed widely. But it is timely to consider their protection because the Soca region is now under major tourist development pressure.
\end{abstract}

Key-words : Austropotamobius pallipes, Austropotamobius torrentium, Astacus astacus, biogeography, taxonomy, protection, Slovenia.

\section{ÉCREVISSES DE LA HAUTE SOCA ET DE LA HAUTE SAVA, SLOVÉNIE.}

\section{RÉSUMÉ}

La biogéographie des écrevisses du nord-ouest de la Slovénie a été étudiée, avec respectivement le cas de la rivière Haute Soca (bassin méditerranéen) et celui de la rivière Sava Dolinka (bassin danubien). L'écrevisse à pieds blancs (Austropotamobius pallipes) se retrouve dans le bassin méditerranéen et celle de torrent ( $A$. torrentium) dans le bassin danubien. Les données morphologiques suggèrent que l'écrevisse à pieds blancs slovène appartient au complexe Austropotamobius pallipes italicus. Ces données biogéographiques et morphologiques soutiennent l'état de la connaissance actuelle, à savoir qu'en Slovénie 
l'écrevisse à pieds blancs appartient à une faune padano-adriatique (= Pô-Adriatique) alors que l'écrevisse de torrent à une faune danubienne. Une troisième espèce, l'écrevisse à pieds rouges (Astacus astacus), a été également retrouvée dans le bassin danubien, mais sa présence n'y aurait pas d'importance biogéographique puisqu'elle est présente et qu'elle a été introduite dans ces deux bassins (méditerranéen et danubien). L'écrevisse à pieds rouges provenant d'un lac slovène, Blejsko jezero, possède des caractères morphologiques spéciaux qui nécessitent de nouvelles études pour déterminer sa position taxonomique. Actuellement, la localisation de l'écrevisse de torrent de la Sava Dolinka est limitée à quelques îlots relictuels (à partir d'une ancienne répartition plus large et détruite par les hommes). Par contre, l'écrevisse à pieds blancs de la Soca a encore une large répartition, mais il est temps de réfléchir à sa protection, car la région Soca est maintenant sous la pression d'un grand développement touristique.

Mots-clés : Austropotamobius pallipes, Austropotamobius torrentium, Astacus astacus, biogéographie, taxonomie, protection, Slovénie.

\section{INTRODUCTION}

Slovenia was the second most productive region for crayfish in the former Habsburg Empire : $17.5 \%$ (19,930 crayfish) of the total catch (113,741 crayfish) in Austria in 1904 came from this region (ANONYMOUS, 1907). Thus, the animal must have been economically important in Slovenia. However, Slovenian crayfish have seldom been studied or reported upon, and such reports are little known by biologists in western Europe. HERFORTMICHIELI $(1973,1979)$ briefly discussed the noble crayfish (Astacus astacus) of Slovenia. Nothing seems to have been published about other crayfish species.

Fortunately, crayfish reports by neighbouring countries (ENTZ, 1914 ; KARAMAN S., 1929 ; KARAMAN M.S., 1962 ; BOTT, 1950 ; ALBRECHT, 1980, 1982a, 1983) can be extrapolated to include Slovenian crayfish. These reports indicate that the Danubian drainage has stone crayfish (Austropotamobius torrentium), and the Mediterranean drainage has white-clawed crayfish (Austropotamobius pallipes). This distribution could be partly verified during our field studies of the Upper Soca River and the Sava Dolinka River in 1995.

\section{METHODS AND RESULTS}

Two water drainages (Danubian, Mediterranean) were studied. The upper part of the Soca (= Isonzo) River was chosen for the Mediterranean drainage, and the upper part of the Sava River, or more precisely the Sava Dolinka, was chosen for the Danubian one.

Information about crayfish distribution was obtained from local people. Also $1 / 50,000$ topographic maps were helpful in locating likely crayfish waters. The animals were caught by hand.

Studies in Slovenia were conducted 5-17 August 1995 on the Upper Soca and the Sava Dolinka. Other sites outside the study area were also visited, in order to have comparable data. In total 29 sites in the Soca drainage, 41 sites in the Sava Dolinka drainage, four sites in the Sava Bohinjka drainage and two sites in the Ljubljanica drainage were inspected (some rivers had several sites). Of these, 19 were determined to be crayfish waters : 16 extant populations and three extinct ones (see Annex and Figure 1). Also in four among these 19 crayfish sites, the crayfish species could not be determined because no specimen could be observed (sites 10,15, 16 and 18). 

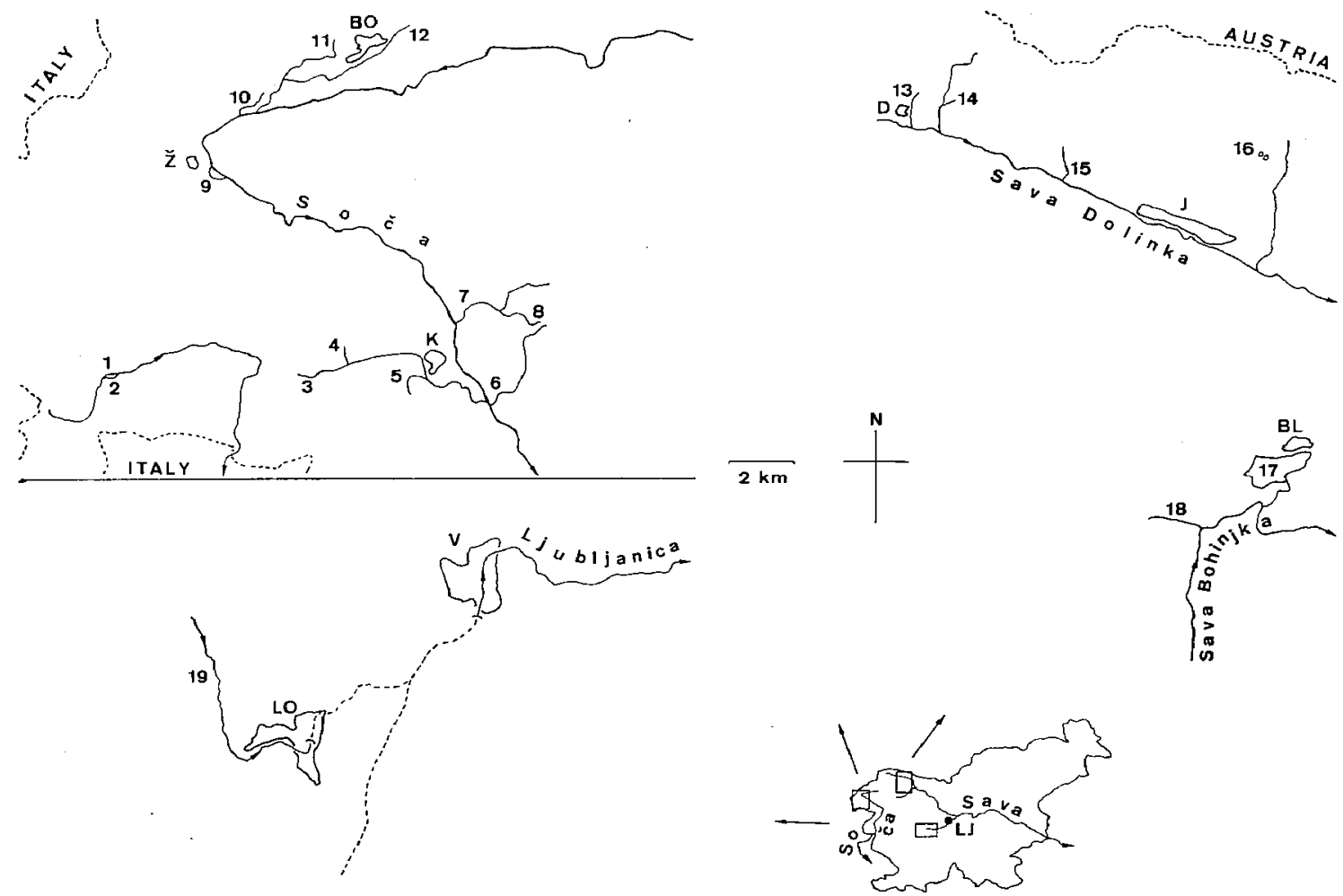

Figure 1

Crayfish distribution map in northwestern Slovenia. Crayfish sites are numbered (see Annex for more about the sites). Towns, BL : Bled, BO : Bovec, D : Dovje, J : Jesenice, K : Kobarid, LJ : Ljubljana, LO : Logatec, V : Vrhnika, Z : Zaga. White-clawed crayfish (Austropotamobius pallipes) : sites 1-9 and 11-12. Stone crayfish (Austropotamobius torrentium) : sites 13-14 and 19. Noble crayfish (Astacus astacus) : sites 17 and 19. Species indeterminate : sites 10, 15-16 and 18.

Figure 1

Répartition géographique des écrevisses au nord-ouest de la Slovénie. Les sites à écrevisses sont numérotés (voir l'Annexe pour les précisions sur les sites). Noms des villes, BL : Bled, BO : Bovec, D : Dovje, J : Jesenice, K : Kobarid, LJ : Ljubljana, LO : Logatec, V : Vrhnika, Z : Zaga. Ecrevisses à pieds blancs (Austropotamobius pallipes) : sites 1-9 et 11-12. Ecrevisses de torrent (Austropotamobius torrentium) : sites 13-14 et 19. Ecrevisses à pieds rouges (Astacus astacus) : sites 17 et 19. Espèce indéterminée : sites 10, 15-16 et 18.

\section{DISCUSSION}

It can therefore be concluded that the Soca drainage has $A$. pallipes (sites : $1,2,3$, $4,5,6,7,8,9,11,12$ ), the Sava drainage has both $A$. torrentium (sites : 13, 14, 19) and A. astacus (sites : 17, 19).

\section{Biogeography}

It is difficult to find a biogeographic reason for the presence of noble crayfish ( $A$. astacus) in the waters examined. The species is present in, and has been stocked into, both the Danubian and Mediterranean drainages (PARENZAN, 1928 ; HERFORT-MICHIELI, 1973), and we have not yet determined its natural (or original) distribution in Europe (see also ALBRECHT, 1980, 1983).

The distribution pattern of $A$. pallipes and $A$. torrentium from our results and the taxonomic data (see below) support the general conception that in Slovenia the white-clawed 
crayfish belongs to a Po-Adriatic fauna and the stone crayfish to a Danubian fauna, and that their distribution generally does not overlap (ALBRECHT, 1980, 1982a, 1982b, 1983 ; LAURENT, 1988).

Site 19 is of interest in term of sympatry : noble crayfish and stone crayfish exist together. Their micro-habitat, however, seems to differ slightly. Noble crayfish live in algae or in burrows made in the river beds, while stone crayfish live under stones or make burrows like noble crayfish. But the present study failed to clearly reveal their segregation mechanism.

\section{Taxonomy}

Noble crayfish (A. astacus) in a Slovenian lake, Blejsko jezero (site 17), differ very much morphologically from those of my personal collection from France, Austria and Greece. They have : big spines on the median rostral ridge (= Rostrummittelkiel) ; the second postorbital ridge (= hinterer Postorbitalknoten) is very visible; no spine on the second postorbital ridge; most often, four spines are present behind the cervical groove (after five specimens analysed, one spine : 10\%; two spines : $10 \%$; four spines : $60 \%$; six spines : $20 \%$ ) ; carapace surface very smooth; every spine is strong if present wherever located on the body; absence of "talon" on the second pleopod on males. A crayfish with these characteristics does not fit the taxonomic criteria of any subspecies of noble crayfish detailed by KARAMAN S. (1929), KARAMAN M.S. (1963) and ALBRECHT $(1980,1982 a)$. Further investigations and new data are necessary in order to define the true taxonomic position of the Blejska jezero's noble crayfish.

According to morphological data from specimens at sites 14 and 19 , the stone crayfish (A. torrentium) in these areas correspond to subspecies $A$. $t$. torrentium or $A . t$. danubicus : symmetric first pleopod on males; absence of "talon" on the male's second pleopod (for four of the five males) ; three to five spines on the third maxilliped merus. Currently it is impossible to define which taxon these Slovenian stone crayfish belong to, because the $A$. $t$. danubicus taxon is not yet clearly defined morphologically (KARAMAN S., 1929 ; KARAMAN M.S., 1962 ; ALBRECHT, 1980, 1982a).

White-clawed crayfish (A. pallipes) in the Soca drainage have the following taxonomic characteristics : the length of the rostral apex is approximately $30.3 \%$ of the rostral length (for 17 specimens); the third maxilliped merus has most often four to six spines (Figure 2); most often one to three spines behind the cervical groove (Figure 2); no bristle on the second pleopod on males; male's first pleopod being either symmetric (four males) or asymmetric (five males). These data indicate that they belong to the A. p. italicus subspecies, whose systematics, however, are not yet well understood (KARAMAN S., 1929 ; KARAMAN M.S., 1962 ; BOTT, 1950, 1972 ; ALBRECHT, 1980, 1982a).

\section{Threats}

Crayfish habitat in this area shows a very contrasting situation. The Sava Dolinka drainage is in dire shape and the Soca drainage still has hope for continued crayfish survival. The Sava Dolinka and its tributaries have been almost totally regulated, e.g., by sand-guard dams, concrete river banks and bottoms, or straightening the watercourses. The car-road network is highly developed. The roads connecting Tarvisio (Italy) - Jesenice (Slovenia) - Villach (Austria) suggest to me that their construction had big negative impacts on crayfish, by disturbed ground running into the water with rain and by destroying natural river banks and beds. Particularly for stone crayfish, the present habitat offers very little survival opportunities in these waters. Pollutions from hotels and houses add serious threats for crayfish. In this region crayfish may still survive in some waters, as in sites 13 and 14, but such locations are sporadic and very isolated, as if these are relics of a former wider distribution. 


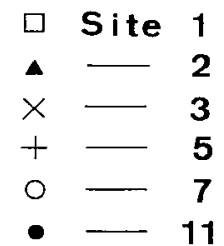

3rd mxp. merus

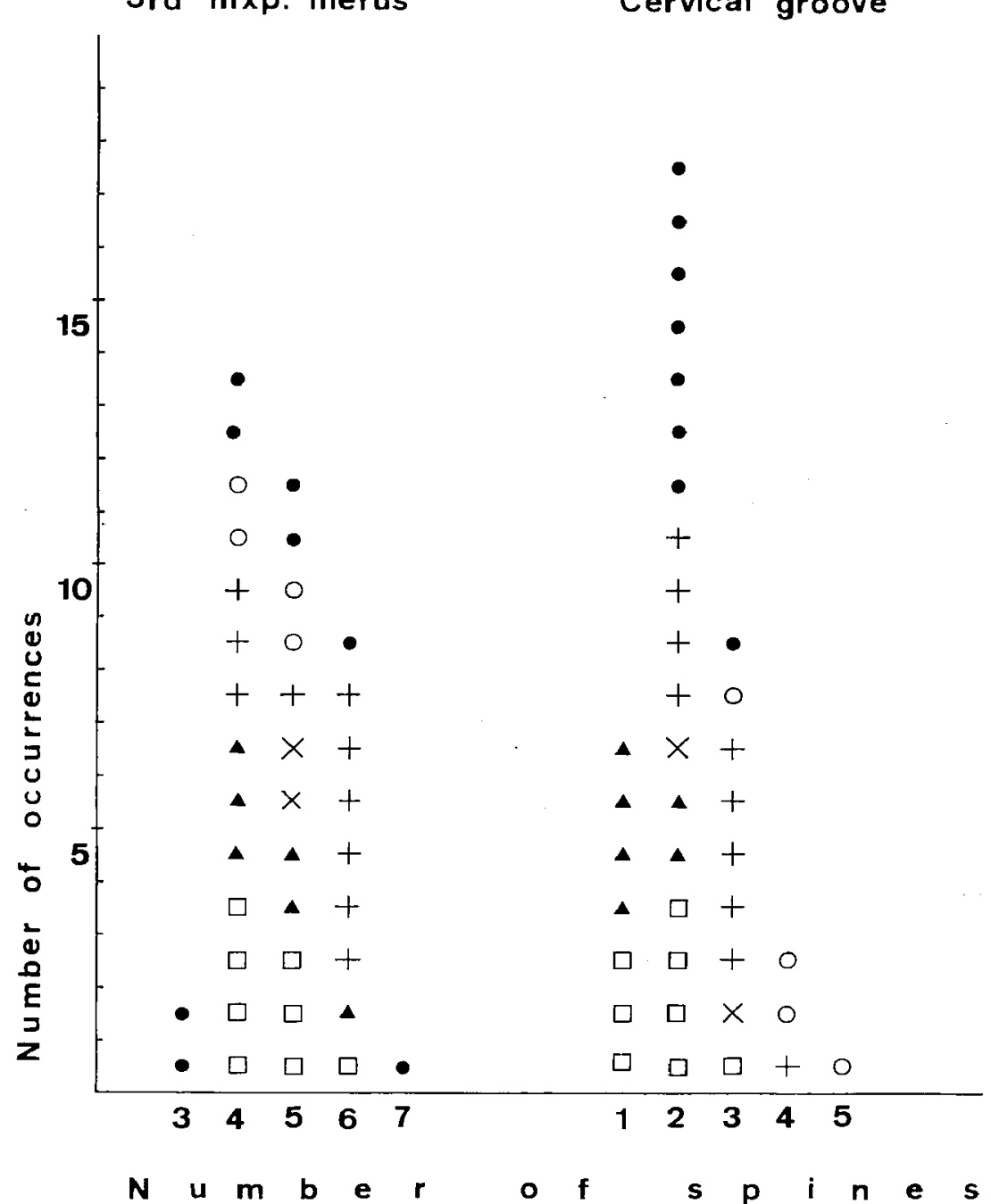

Figure 2

Histogram of numbers of spines on the third maxilliped merus and behind the cervical groove of the white-clawed crayfish (Austropotamobius pallipes) from the Soca drainage, Slovenia. As the spine numbers are not totally symmetric and differ slightly, the left and the right, the counting was carried out for both sides. 19 crayfish from six sites gave the data for 38 merus and 38 cervical grooves. For the site location, see Annex and Figure 1.

Figure 2

Histogramme de nombres d'épines sur le mérus du troisième maxillipède et en arrière du sillon cervical chez les écrevisses à pieds blancs (Austropotamobius pallipes) du bassin de la Soca, Slovénie. Comme les nombres d'épines ne sont pas totalement symétriques et diffèrent légèrement, la gauche et la droite, les épines des deux côtés ont été prises en compte. 19 spécimens capturés sur les six sites ont fourni les données pour 38 mérus et 38 sillons cervicaux. Pour la localisation des sites, voir l'Annexe et la Figure 1. 
The constrasting situation of the Soca shows an image of the Sava Dolinka 20 years ago. Many parts of the Soca and its tributaries are still unregulated. Pollution is not much of a problem yet. Because this region is now under development pressure, we have to take protective measures to save the crayfish.

The following suggestions are made in the interest of crayfish preservation :

- no more water regulation, particularly on small creeks and side-channels of the Soca ;

- no more destruction of wetlands and small creeks;

- forbid or reduce the use of pesticides for agriculture ;

- all present houses/hotels/camping areas/industries are advised to have used-water treatment systems, and all future construction should be required to have this equipment ;

- in order to avoid introduction of crayfish diseases, never introduce any crayfish into any waters in the whole area;

- when a road, bridge or other construction does occur, special measures for protecting crayfish and its habitat (including water) should be taken, e.g., disturbed ground, sand, and gravel should be covered or coated in order to not allow them to run into rivers with rain ;

- if a crayfish habitat destruction is unavoidable because of a construction, careful crayfish relocalization should be considered as a salvage means.

The Soca area is now being developed for tourism because of its mountains and the Soca River. This fluvial tourism (rafting, fishing, swimming), which is quite unique in Europe, is supported by the Soca's water quality and big flow. Construction of new hotels, houses, roads and bridges, new land management schemes, and draining/canalization of waters/rivers, are only a question of time. Pollution from sewage and agriculture, as well as damming rivers for water supplies, will worsen the situation. All these could destroy the water and the Soca. The disappearance of crayfish can be a first sign of the decline of fluvial tourism.

Crayfish fishing is now forbidden in Slovenia. But this alone will not save the crayfish, as shown by many failed protections of fishing regulations from all over Europe. Their true enemies are neither fishermen nor poachers, but our life style and land and water management. There can be a way to live together, humans and crayfish, and the proof is that they could survive until now in the Soca area.

\section{Annex}

Crayfish sites in Slovenia (see Figure 1 for geographic position).

Annexe

Sites à écrevisses en Slovénie (voir Figure 1 pour la position géographique).

Site $1\left(46^{\circ} 14^{\prime} 34^{\prime \prime} \mathrm{N}, 13^{\circ} 26^{\prime} 41^{\prime \prime} \mathrm{E}, 290 \mathrm{~m}\right.$ above sea-level) : the Nadiza (= Natisone) at the Podbela Bridge. A tributary of the Soca, it leaves Slovenia and joins the Soca in Italy. Date : 7 Aug. 1995. Species: A. pallipes. 4 specimens kept (2 males, 2 females). 
Site $2\left(46^{\circ} 14^{\prime} 31^{\prime \prime} \mathrm{N}, 13^{\circ} 26^{\prime} 39^{\prime \prime} \mathrm{E}, 290 \mathrm{~m}\right.$ a.s.l.) : the Nadiza Side-Channel at the small Podbela Bridge. Date : 7 Aug. 1995. Species : A. pallipes. 3 specimens kept (1 male, 2 females). Dense population.

Site $3\left(46^{\circ} 14^{\prime} 32^{\prime \prime} \mathrm{N}, 13^{\circ} 31^{\prime} 47^{\prime \prime} \mathrm{E}, 240 \mathrm{~m}\right.$ a.s.l.) : the Idrija above the road Robic-Suzid. The Idrija is a right bank tributary of the Soca at Kobarid, not to be confused with another Idrija (= Judrio) which goes into Italy. Date : 5 Aug. 1995. Species: A. pallipes. 1 specimen kept (1 female). Small population.

Site $4\left(46^{\circ} 14^{\prime} 55^{\prime \prime} \mathrm{N}, 13^{\circ} 32^{\prime} 40^{\prime \prime} \mathrm{E}, 250 \mathrm{~m}\right.$ a.s.l.) : no name brook at the religious sign $1 \mathrm{~km}$ east of Staro Selo. This brook is a left bank tributary of the Idrija. Date : 10 Aug. 1995. Species: A. pallipes. Observed only 1 adult male and 1 adult female exuvia. No specimen kept. Very small population.

Site $5\left(46^{\circ} 14^{\prime} 18^{\prime \prime} \mathrm{N}, 13^{\circ} 34^{\prime} 08^{\prime \prime} \mathrm{E}, 295 \mathrm{~m}\right.$ a.s.l.) : no name brook at Svino, near Kobarid. This is a right bank tributary of the Idrija. Date : 5 Aug. 1995. Species : A. pallipes. 5 specimens kept ( 3 males, 2 females). This is not a natural population. $400 \mathrm{~m}$ below Svino, the brook has a waterfall (about $8 \mathrm{~m}$ high), which was formerly a barrier for crayfish. They lived in the brook below the waterfall and in the Idrija. In 1952 or 1953, Idrija crayfish were brought up above the waterfall by Joze KURINCICl of Svino (B. KURINCICl, 1995, pers. comm.). Today, crayfish form a good population in this tiny brook above the waterfall, but they are absent below (because of water eutrophication caused by pollution in Svino).

Site $6\left(46^{\circ} 14^{\prime} 13^{\prime \prime} \mathrm{N}, 13^{\circ} 36^{\prime} 47^{\prime \prime} \mathrm{E}, 225 \mathrm{~m}\right.$ a.s.I.) : the Rocica, a left bank tributary of the Soca at Ladra. Date : 6 Aug. 1995. Species: A. pallipes. No specimen kept. Small population. It seems the crayfish are present only in the lower part of the Rocica below the Ladra Waterfall and they are absent in the upper (550 $\mathrm{m}$ a.s.l.) and middle (360 $\mathrm{m}$ a.s.l.) parts of the Rocica.

Site $7\left(46^{\circ} 15^{\prime} 38^{\prime \prime} \mathrm{N}, 13^{\circ} 35^{\prime} 33^{\prime \prime} \mathrm{E}\right.$, presence confirmed from 220 to $300 \mathrm{~m}$ a.s.I.) : the Kozjak, a left bank tributary of the Soca. Dates : 16 and 17 Aug. 1995. Species: $A$. pallipes. 4 specimens kept ( 2 males, 2 females). There is questionable information about the presence of stone crayfish $(A$. torrentium) in this river, but had not been verified $(N$. BUDIHNA, 1995, oral comm.). The present investigation rejects this information and, at the same time, verifies our conception that all rivers flowing into the Adriatic Sea generally belong to the distribution area for the white-clawed crayfish (A. pallipes) and not to that of the stone crayfish. The exceptions are due to dispersion of the Danubian faunae from formerly the western Paratethys Basin in the Tertiary era, such as tributaries of the Krka and Cetina Rivers (Dalmatia) (ALBRECHT 1980, 1983). Two (1 male and 1 female) of the collected specimens were given to the Zavod za Ribistvo in Ljubljana (N. BUDIHNA) for further studies.

Site $8\left(46^{\circ} 15^{\prime} 27^{\prime \prime} \mathrm{N}, 13^{\circ} 37^{\prime} 20^{\prime \prime} \mathrm{E}, 590 \mathrm{~m}\right.$ a.s.l.) : the Pod-Podvalom, a tiny brook near Dreznica, belonging to the Kozjak drainage. Date : 6 Aug. 1995. Species : A. pallipes. No specimen kept. Very small population.

Site $9\left(46^{\circ} 18^{\prime} 04^{\prime \prime} \mathrm{N}, 13^{\circ} 29^{\prime} 25^{\prime \prime} \mathrm{E}, 330 \mathrm{~m}\right.$ a.s.I.) : the Proda Channel near Zaga, this is a side channel of the Soca. Dates : 8 and 10 Aug. 1995. Species : A. pallipes. No specimen kept. Small population.

Site $10\left(46^{\circ} 19^{\prime} 17^{\prime \prime} \mathrm{N}, 13^{\circ} 30^{\prime} 33^{\prime \prime} \mathrm{E}, 350 \mathrm{~m}\right.$ a.s.I. $)$ : the Vedice, a right bank tributary of the Soca near Zvikar. Date : 7 Aug. 1995. No crayfish observed. Species : indeterminate. Between Podklopca and Zvikar, there is a large swamp, where many crayfish lived in the 1960 's, but disappeared since then. Its head waters (the Vedice) had crayfish still in the 
1980 's, but they declined since then. The last specimens (three crayfish) would have been seen in 1993 by Philip KOVACE of Podklopca (M. MOHAR, 1995, oral comm.). The Vedice therefore seems to have no more crayfish.

Site $11\left(46^{\circ} 20^{\prime} 13^{\prime \prime} \mathrm{N}, 13^{\circ} 32^{\prime} 22^{\prime \prime} \mathrm{E}, 470 \mathrm{~m}\right.$ a.s.I.) : the Andrena Voda near Bovec, a small brook which joins the Rocica and the Glijun before joining the Soca. Date : 10 Aug. 1995. Species : A. pallipes. 4 specimens kept (2 males, 2 females).

Site $12\left(46^{\circ} 20^{\prime} 33^{\prime \prime} \mathrm{N}, 13^{\circ} 34^{\prime} 01^{\prime \prime} \mathrm{E}, 460 \mathrm{~m}\right.$ a.s.I.) : the Rakunca near Bovec, a small brook which joins the Geres and the Glijun before joining the Soca. Date : 9 Aug. 1995. Species : A. pallipes. No specimen kept. Small population.

Site $13\left(46^{\circ} 28^{\prime} 18^{\prime \prime} \mathrm{N}, 13^{\circ} 57^{\prime} 04^{\prime \prime} \mathrm{E}, 810 \mathrm{~m}\right.$ a.s.l.) : no name brook at Dovje, a left bank tributary of the Sava Dolinka. Date : 11 Aug. 1995. Species : A. torrentium. 2 specimens kept (1 male, 1 female). Small population.

Site $14\left(46^{\circ} 28^{\prime} 12^{\prime \prime} \mathrm{N}, 13^{\circ} 57^{\prime} 45^{\prime \prime} \mathrm{E}, 790 \mathrm{~m}\right.$ a.s.l.) : no name brook near Dovje, a left bank tributary of the Mlinca which is a left bank tributary of the Sava Dolinka. Date :12 Aug. 1995. Species : A. torrentium. No specimen kept. Very small population.

Site $15\left(46^{\circ} 27^{\prime} 08^{\prime \prime} \mathrm{N}, 14^{\circ} 00^{\prime} 45^{\prime \prime} \mathrm{E}, 625 \mathrm{~m}\right.$ a.s.I.) : the Dobrosnik at Hrusica, a left bank tributary of the Sava Dolinka. Date : 14 Aug. 1995. No crayfish observed. Species : indeterminate. According to local information in Hrusica, this brook had crayfish till about 1975 when many sand-guard dams were constructed in the brook; crayfish are now gone from this area. This brook is very steep.

Site $16\left(46^{\circ} 27^{\prime} 19^{\prime \prime} \mathrm{N}, 14^{\circ} 05^{\prime} 26^{\prime \prime} \mathrm{E}, 970 \mathrm{~m}\right.$ a.s.l.) : two artificial ponds at Dom Pristava, in the Jabornik drainage, a left bank tributary of the Sava Dolinka near Jesenice. Date: 14 Aug. 1995. No crayfish observed. Species: indeterminate. According to the owner of Dom Pristava, the ponds had big crayfish till about 1975, but have since disappeared.

Site $17\left(46^{\circ} 21^{\prime} 51^{\prime \prime} \mathrm{N}, 1^{\circ} 05^{\prime} 47^{\prime \prime} \mathrm{E}, 475 \mathrm{~m}\right.$ a.s.l.) : Blejsko jezero, a lake near Bled, forming a left bank tributary of the Sava Bohinjka. Date : 15 Aug. 1995. Species : A. astacus. 5 specimens kept ( 2 males, 3 females). No large specimen seen.

Site $18\left(46^{\circ} 20^{\prime} 55^{\prime \prime} \mathrm{N}, 14^{\circ} 03^{\prime} 36^{\prime \prime} \mathrm{E}, 540 \mathrm{~m}\right.$ a.s.I. $)$ : the Suha, a very steep left bank tributary of the Sava Bohinjka at Bohinjska Bela. Date : 15 Aug. 1995. Species : indeterminate. No crayfish was observed, because I could not reach the crayfish area. According to local information in Bohinjska Bela, small crayfish are present in this brook, they live in just below the waterfall "Slap pod Iglico".

Site $19\left(45^{\circ} 56^{\prime} \mathrm{N}, 14^{\circ} 12^{\prime} \mathrm{E}, 510 \mathrm{~m}\right.$ a.s.l. $)$ : the Reka near Logatec, a tributary of the Logascica which is a karst river disappearing underground at Logatec. The water emerges at Vrhnika and forms the Ljubljanica flowing through Ljubljana, which is a right bank tributary of the Sava. Date : 16 Aug. 1995. Species: A. torrentium and A. astacus. 5 specimens of $A$. torrentium kept (4 males, 1 female) but none of $A$. astacus. Both species have large populations.

\section{ACKNOWLEDGEMENTS}

Although I did not name many of my Slovenian crayfish informers, I really thank them, their help was immeasurable. I also thank F.W. KIRCHEIS for correcting the text. 


\section{BIBLIOGRAPHY}

ALBRECHT H., 1980. Untersuchungen zur Evolution und Systematik der europäischen Flußkrebse und ihrer Verwandten. Dissertation, Fachbereich Biologie (Zoologie), Phillips-Universität Marburg, Marburg an der Lahn, $v+221 \mathrm{p}$.

ALBRECHT H., 1982a. Das System der europäischen Flußkrebse (Decapoda, Astacidae) : Vorschlag und Begründung. Mitt. Hamb. Zool. Mus. Inst., 79, 187-210.

ALBRECHT H., 1982b. On the origin of the Mediterranean crayfishes. Quad. Lab. Tecnol. Pesca, 3, 355-362.

ALBRECHT H., 1983. Besiedlungsgeschichte und ursprünglich holozäne Verbreitung der europäischen Flußkrebse. Spixiana, 6, 61-77.

ANONYMOUS, 1907. Die Binnen-Fischerei in Österreich. Statistische Monatschrift, Neue Folge, 12 (Beilage 1), 159 p. Brünn (= Brno, Slovakia).

BOTT R., 1950. Die Flußkrebse Europas (Decapoda, Astacidae). Abh. Senckenb. Naturforsch. Ges., 483, 1-36 + 6 Plates.

BOTT R., 1972. Besiedlungsgeschichte und Systematik der Astaciden West-Europas unter besonderer Berücksichtigung der Schweiz. Rev. Suisse Zool., 79, 387-408 +4 Plates.

BUDIHNA N., 1995, oral comm. Zavod za Ribistvo Ljubljana, Zupanciceva 9, 61000 Ljubljana, Slovenia.

ENTZ G., 1914. Ueber die Flußkrebse Ungarns. Math. Naturwiss. Ber. Ungarn, Jahrgang 1912, 30, 67-127 + 4 Plates.

HERFORT-MICHIELI T., 1973. Der Krebsbestand und seine Erneuerung in Slowenien. In ABRAHAMSSON S. (ed.), Freshwater Crayfish, vol. 1, 97-104, Studentlitteratur, Lund (Sweden).

HERFORT-MICHIELI T., 1979. L'écrevisse à pieds rouges en Slovénie depuis 1972. In LAURENT P.J. (ed.), Freshwater Crayfish, vol. 4, 185-189, Institut National de la Recherche Agronomique, Thonon-les-Bains (France).

KARAMAN S., 1929. Die Potamobiiden Jugoslaviens. Glas. Zemalj. Muz. Bosni Herceg., 41, 147-150.

KARAMAN M.S., 1962. Ein Beitrag zur Systematik der Astacidae (Decapoda). Crustaceana, 3, 173-191.

KARAMAN M.S., 1963. Studie der Astacidae (Crustacea, Decapoda). Hydrobiologia, 22, $111-132$.

KURINCICI B., 1995, pers. comm. Svino 12, 65222 Kobarid, Slovenia.

LAURENT P.J., 1988. Austropotamobius pallipes and A. torrentium, with observations on their interactions with other species in Europe. In HOLDICH D.M. and LOWERY R.S. (eds.), Freshwater crayfish : biology, management and exploitation, 341-364 + 426-479, Chapman and Hall, London.

MOHAR M., 1995, oral comm. Podklopca 7, 65230 Bovec, Slovenia.

PARENZAN P., 1928. Sui Crostacei limnicoli della regione Giulia e specialmente sul gruppo dei Cladoceri. Arch. Zool. Ital., 12 (2), 219-245 + Plate 8. 